\title{
Analysis of combustion process in industrial gas engines powered with high methane and nitrified low-calorific gases
}

\begin{abstract}
The paper presents the results of an investigation of gas engines used in the Polish system of natural gas transmission. The investigation concerned both four-stroke and two-stroke engines. The engines were fed with two kinds of gas fuellow-calorific natural gas containing $54.5 \%$ of methane, and with high-methane (up to $95 \%$ ) natural gas. Combustion in both types of engines with different methods of mixture supply into the cylinder was analysed for different parameters. The paper also presents numerical computations of basic physical values characterizing combustion of gas fuels in engines. The computations were made with Cantera numerical code based on the mechanism of elementary reactions occurring while burning methane GRI 3.0 for various molar fractions of methane in the gas fuel.
\end{abstract}

Key words: gas engine, natural gas, misfiring, Cantera

\section{Analiza procesu spalania w przemysłowych silnikach gazowych zasilanych gazami wysokometanowymi i niskokalorycznymi zaazotowanymi}

\begin{abstract}
W artykule przedstawiono rezultaty badań silników gazowych wykorzystywanych w polskim systemie przesylowym gazu ziemnego. Badania te wykonano na silnikach cztero- $i d w u s u w o w y c h$. Jednostki te byty zasilane dwoma rodzajami paliw gazowych: niskokalorycznym gazem ziemnym o zawartości metanu wynoszącej 54,5\% oraz wysokometanowym gazem ziemnym zawierającym do $95 \%$ metanu. Analizie poddano proces spalania w wyżej wymienionych silnikach dla różnych parametrów eksploatacyjnych oraz różnych metod doprowadzenia mieszanki do cylindra. Przedstawiono również obliczenia numeryczne podstawowych wielkości fizycznych charakteryzujacych proces spalania paliw gazowych w silnikach. Obliczenia przeprowadzono przy użyciu kodu numerycznego Cantera, bazujacego na mechanizmie reakcji elementarnych zachodzacych przy spalaniu metanu GRI 3.0 dla różnych udziatów molowych metanu w gazie paliwowym.
\end{abstract}

Słowa kluczowe: silnik gazowy, gaz ziemny, wypadanie zapłonów, Cantera

\section{Introduction}

Gas engines are used in industry both in electricity generation as power generators and in actuating devices, such as compressors or pumps. The latter use of gas engines is common in gas industry, e.g. in the system of transmission of natural gas from Russia through Poland to Western Europe and for domestic transport of gas in Poland. At present about 100 units of different capacity geared to the size of gas compressors operate within the transmission system. Engines used in gas transmission have a workload of over $8000 \mathrm{hrs}$ per year, which, when combined with high capacities generated-sometimes exceeding $2 \mathrm{MW}$ - makes it essential for their work to be optimized for fuel consumption and emission of toxic compounds. The most important pollutants from burning natural gas in gas engines are nitric oxides $\left(\mathrm{NO}_{\mathrm{x}}\right)$, and unburned hydrocarbons, such as methane $\left(\mathrm{CH}_{4}\right)$ and formaldehyde $\left(\mathrm{CH}_{2} \mathrm{O}\right)$.

The Gas Technology Laboratory at Poznan University of Technology has, for over ten years now, collaborated with various companies of the PGNiG Group in investigations of engines used in the high-pressure transmission system in Poland. The system includes gas turbines driving flow compressors and, first of all, gas piston engines for piston compressors. The task of the engine is to drive compressors so as to raise the pressure of the transported gas from

\section{Wprowadzenie}

Silniki gazowe wykorzystywane są w przemyśle, zarówno w energetyce zawodowej do napędu generatorów prądu, jak również do napędu urządzeń wykonawczych typu: sprężarki oraz pompy. Drugie z wymienionych zastosowań silników gazowych jest powszechne w przemyśle gazowniczym. Wykorzystano je w systemie przesyłowym gazu ziemnego transportowanego z Rosji przez Polskę do krajów Europy Zachodniej oraz w krajowym przesyle gazu. Obecnie w systemie tym pracuje około 100 jednostek o różnej mocy, dostosowanej do wielkości napędzanych kompresorów gazu. Silniki pracujące na potrzeby przesyłu paliw gazowych eksploatowane są zwykle ponad 8000 godzin w ciągu roku, co w połączeniu z wysokimi wartościami mocy generowanymi przez te jednostki - przewyższające nawet $2 \mathrm{MW}$ - sprawia, że ich praca powinna być optymalizowana pod względem zużycia paliwa oraz emisji związków toksycznych. Do głównych zanieczyszczeń emitowanych podczas spalania gazu ziemnego w silnikach gazowych zaliczamy tlenki azotu $\left(\mathrm{NO}_{\mathrm{x}}\right)$ oraz niespalone węglowodory, wśród których wyróżnić można metan $\left(\mathrm{CH}_{4}\right)$ i formaldehyd $\left(\mathrm{CH}_{2} \mathrm{O}\right)$.

Laboratorium Technologii Gazowych Politechniki Poznańskiej od ponad 10 lat we współpracy z różnymi podmiotami należącymi do grupy kapitałowej PGNiG prowadzi 
within the range of 17 to 55 bar (for pipelines with diameter less than 46 inches) and within the range of 50 to 80 bar for pipelines with diameters over 46 inches. The average fuel consumption of the gas engine (piston engine, turbine) driving the compressor is from 1.1 to $1.5 \%$ of the gas transported and depends on the efficiency of the system engine-compressor.

The paper presents the investigation results for two types of piston engines commonly used in gas transmission in Poland:

- two-stroke Cooper-Bessemer engine GMVH with a common shaft for the engine and the compressor,

- four-stroke Waukesha engine series AT, connected to the compressor with a clutch.

Such engines are normally driven by the gas transported. Depending on the final use of the gas and its composition, we may deal with high-methane or nitrified lowcalorific gases. The paper presents the results obtained for two types of gas fuel with compositions given in Table 1. Table 2 presents the basic parameters of the units investigated.

Because of the strategically important task of ensuring the stability of gas fuels supplies performed by the units gas engine-compressor, the work of every system is monitored on-line with the recording of the most important parameters, such as exhaust gas temperature, pressure before and after the turbocharger, speed of the engine and compressor. Additionally for some piston engines, the process of indicating can be carried out, which helps to determine the quality of the combustion process.
Table 1. Molar fraction composition of high methane and nitrified low-calorific gases

Tabela 1. Skład molowy gazów wysokometanowego i niskokalorycznego zaazotowanego

\begin{tabular}{|c|l|c|c|c|}
\hline Pos./Lp. & \multicolumn{1}{|c|}{$\begin{array}{c}\text { Name of the } \\
\text { component/nazwa } \\
\text { sktadnika }\end{array}$} & $\begin{array}{c}\text { Formula/ } \\
\text { wzór }\end{array}$ & $\begin{array}{c}\text { High methane/ } \\
\text { gaz wysoko- } \\
\text { metanowy }\end{array}$ & $\begin{array}{c}\text { Nitrified low-calorific } \\
\text { gas/gaz niskokalory- } \\
\text { czny zaazotowany }\end{array}$ \\
\hline 1 & methane/metan & $\mathrm{CH}_{4}$ & 95.1 & 54.5 \\
\hline 2 & ethane/etan & $\mathrm{C}_{2} \mathrm{H}_{6}$ & 1.5 & 0.39 \\
\hline 3 & propane/propan & $\mathrm{C}_{3} \mathrm{H}_{8}$ & 0.26 & 0.02 \\
\hline 4 & $\begin{array}{l}\text { higher hydro- } \\
\text { carbons/wyższe } \\
\text { węglowodory }\end{array}$ & $\mathrm{C}_{\mathrm{x}} \mathrm{H}_{\mathrm{y}}$ & 0.017 & 0.27 \\
\hline 5 & nitrogen/azot & $\mathrm{N}_{2}$ & 3.0 & 44.2 \\
\hline 4 & hydrogen/wodór & $\mathrm{H}_{2}$ & 0.0 & 0.0 \\
\hline 9 & $\begin{array}{l}\text { carbon dioxide/ } \\
\text { dwutlenek węla }\end{array}$ & $\mathrm{CO}_{2}$ & 0.0 & 0.265 \\
\hline 10 & helium/hel & $\mathrm{He}$ & 0.0 & 0.335 \\
\hline
\end{tabular}

badania silników wykorzystywanych w polskim wysokociśnieniowym systemie przesyłowym. W skład tego systemu wchodzą turbiny gazowe napędzające sprężarki przepływowe oraz przede wszystkim tłokowe silniki gazowe napędzające sprężarki łłokowe. Zadaniem silników jest dostarczenie napędu do sprężarek w celu podniesienia ciśnienia gazu transportowanego w zakresie od 17 do 55 bar (dla rurociągów o średnicy mniejszej niż 46 cali) i zakresie od 50 do 80 bar dla rurociągów o średnic powyżej 46 cali. Średnie zużycie gazu paliwowego silnika (silnik tłokowy, turbina) napędzającego sprężarkę wynosi od 1,1 do 1,5 \% ilości tłoczonego gazu i zależy od sprawności układu silnik-sprężarka.

Artykuł prezentuje wyniki badań dla dwóch typów silników tłokowych powszechnie stosowanych w polskim systemie przesyłowym gazu:

Table 2. Basic parameters of gas engines

Tabela 2. Podstawowe dane silników gazowych

\begin{tabular}{|c|c|c|}
\hline Engine/silnik & Cooper Bessemer GMVH & Waukesha AT \\
\hline Engine type/typ silnika & two stroke/dwusuwowy & four stroke/czterosuwowy \\
\hline Intake/uktad dolotowy & $\begin{array}{c}\text { turbocharger with intercooler/ turbodoładowanie } \\
\text { z chtodnica powietrza doładowującego }\end{array}$ & $\begin{array}{c}\text { turbocharger with intercooler/ } \\
\text { turbodoladowanie z chtodnica powietrza } \\
\text { dotadowujacego }\end{array}$ \\
\hline Fuel system/uktad paliwowy & $\begin{array}{l}\text { direct injecion - poppet valve/bezpośredni wtrysk } \\
\text { paliwa - zawór grzybkowy }\end{array}$ & $\begin{array}{c}\text { carburetor, prechamber/gaźnik, komora } \\
\text { wstępnego spalania }\end{array}$ \\
\hline $\begin{array}{l}\text { Fuel system pressure/ciśnienie gazu } \\
\text { paliwowego }\end{array}$ & $2.1-3.5$ bar & $3.1-4.14$ bar \\
\hline Number of cylinders/liczba cylindrów & 12 in V configuration/12 w uktadzie $V$ & (12 in V configuration/12 w uktadzie $V$ \\
\hline Number of valves/liczba zaworów & $\begin{array}{c}\text { none - cross scavenging/brak-przeptukanie } \\
\text { poprzeczne }\end{array}$ & four per cylinder/cztery na cylinder \\
\hline Bore x stroke/średnica x skok & $\begin{array}{c}355.6 \text { x } 374.14 \mathrm{~mm} \text { - out. } 355.6 \text { x } 372.18 \mathrm{~mm} \\
\text { - inn. (out. - outer row/zew. - zewnętrzny rząd } \\
\text { cylindrów), (in. - inner row/wew.- wewnętrzny } \\
\text { rząd cylindrów) }\end{array}$ & $275 \times 300 \mathrm{~mm}$ \\
\hline Piston displacement/pojemność skokowa & $444.73 \mathrm{dm}^{3}$ & $214 \mathrm{dm}^{3}$ \\
\hline Compression ratio/stopień sprężania & 9.62:1 - out./zew. 9.60:1 - inn./wew. & $9.0: 1$ \\
\hline Rated speed/nominalna prędkość obrotowa & $330 \mathrm{rpm} / \mathrm{obr} / \mathrm{min}$ & $800-1000 \mathrm{rpm} / \mathrm{obr} / \mathrm{min}$ \\
\hline $\begin{array}{l}\text { Maximum speed/maksymalna prędkość } \\
\text { obrotowa }\end{array}$ & $360 \mathrm{rpm} / \mathrm{obr} / \mathrm{min}$ & $1000 \mathrm{rpm} / \mathrm{obr} / \mathrm{min}$ \\
\hline Rated power/nominalna moc & $1825 \mathrm{~kW}$ at $330 \mathrm{rpm} / \mathrm{obr} / \mathrm{min}$ & $2300 \mathrm{~kW}$ at $1000 \mathrm{rpm} / \mathrm{obr} / \mathrm{min}$ \\
\hline
\end{tabular}




\section{Numerical measurements of the combustion process}

Due to its great dynamics and high pressures involved, combustion in piston gas engines is difficult to describe with simple numerical programs. Thus, the present chapter is devoted to the presentation of numerical computations of the basic physical parameters defining the process of combustion of gas fuels in gas engines.

The computations were made with Cantera numerical code, which makes it possible to calculate the basic parameters of combustion with a unidimensional model of flame propagation based on the mechanism of chemical reactions GRI 3.0 [1]. The model includes over 400 elementary reactions occurring in combustion. The calculations were made for operating parameters typical of gas piston engines, such as pressure $P=1-40$ bar, excess air coefficient $\lambda=1.8$ and temperature of the mixture in the range of $300-500 \mathrm{~K}$. The computations refer to two types of gas fuels with compositions as presented in Table 1.

\section{Adiabatic flame temperature}

Adiabatic flame temperature can be computed with a number of equations describing the process of fuel oxidation in a non-equilibrium mechanism in which only the duration of combustion of the mixture in the front of the flame is considered. The results of the calculation of the adiabatic temperature of combustion are shown in Fig. 1a and Fig. $1 \mathrm{~b}$.

a)

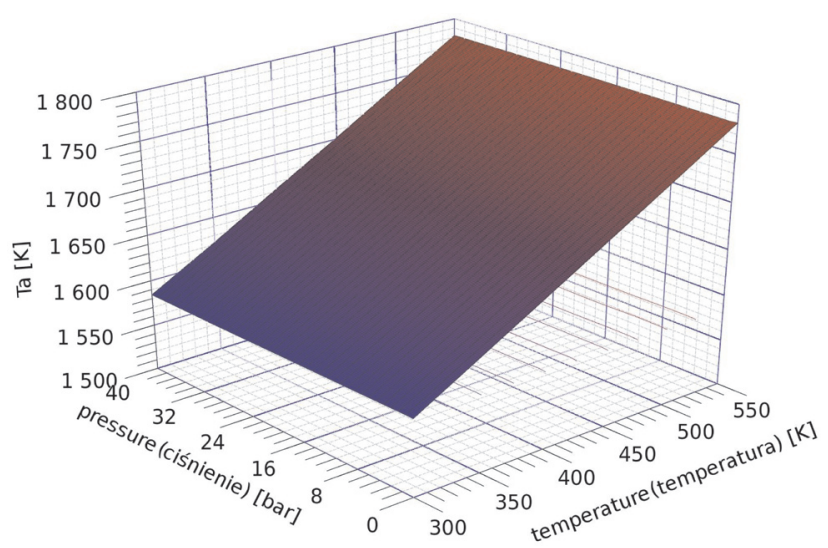

- silnik dwusuwowy Cooper-Bessemer GMVH ze wspólnym wałem dla silnika i sprężarki,

- silnik czterosuwowy Waukesha serii AT połączony ze sprężarką Ariel za pomocą sprzęgła.

Silniki te zasadniczo są zasilane gazem transportowanym. W zależności od zastosowania oraz składu gazu transportowanego mogą to być gazy wysokometanowe lub niskokaloryczne zaazotowane. W pracy przedstawiono wyniki pomiarów dla dwóch paliw gazowych o składach podanych w tabeli 1 . W tabeli 2 zestawiono podstawowe parametry techniczne badanych jednostek.

Ze względu na strategiczne zadania realizowane przez układy silnik gazowy-sprężarka (stabilność dostaw paliw gazowych) praca jednostek jest monitorowana online oraz zapisywane są najważniejsze parametry pracy, takie jak: temperatura spalin, ciśnienie przed i za turbosprężarką, prędkość obrotowa silnika oraz sprężarki. Niektóre silniki tłokowe mają także dodatkowo możliwość przeprowadzenia procesu indykowania, co pomaga w ustaleniu jakości procesu spalania.

\section{Obliczenia numeryczne procesu spalania}

Spalanie w tłokowych silnikach gazowych ze względu na jego dynamikę oraz panujące wysokie ciśnienia jest procesem trudnym do opisania za pomocą prostych programów numerycznych, dlatego w tym rozdziale będą przedstawione wyniki obliczeń numerycznych podstawowych wielkości fizycznych opisujących proces spalania paliw gazowych jakimi zasilane są silniki gazowe.

b)

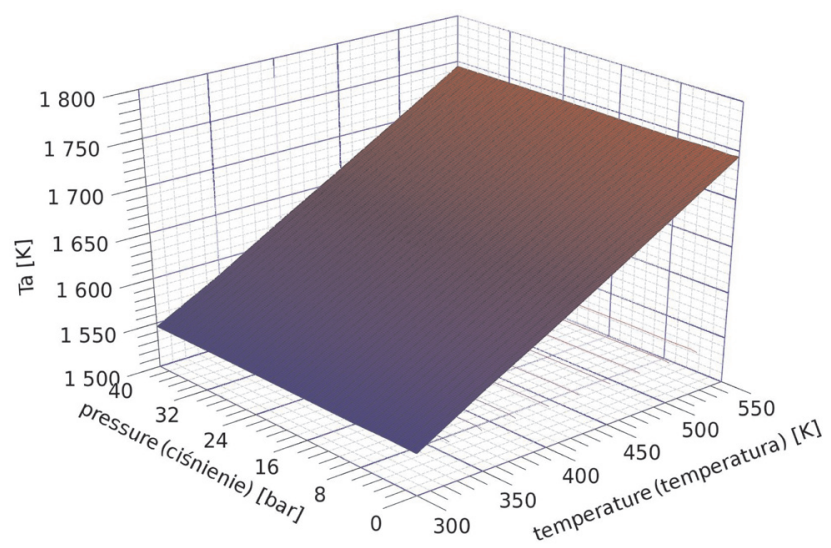

Fig. 1. Adiabatic flame temperature as a function of ambient pressure and initial temperature; $\mathrm{a}-$ high methane, $\lambda=1.8, \mathrm{~b}-$ nitrified low-calorific gas, $\lambda=1.8$

Rys. 1. Adiabatyczna temperatura płomienia $w$ zależności od ciśnienia otoczenia i temperatury początkowej; a - gaz wysokometanowy, $\lambda=1,8$, b-gaz niskokaloryczny zaazotowany

The maximum combustion temperature strongly depends on the kind of fuel and on the conditions of the combustion process. The temperature plays a major role in the appearance of nitric oxides in the combustion chamber in accordance with the thermal mechanism of NO formation described by Zeldowicz [2] as reactions (1) and (2) supplemented by reaction (3) explained by Lavoie [3].
Obliczenia wykonano przy użyciu kodu numerycznego Cantera, który umożliwia obliczenia podstawowych właściwości procesu spalania w jednowymiarowym modelu propagacji płomienia, opierając się na mechanizmie reakcji chemicznych GRI 3.0 [1]. Model ten uwzględnia ponad 400 elementarnych reakcji chemicznych towarzyszących procesowi spalania. Obliczenia wykonano dla parametrów eksploatacyjnych typowych dla gazowych silników tłoko- 


$$
\begin{aligned}
& \mathrm{O}+\mathrm{N}_{2} \stackrel{\mathrm{k}_{1}}{\rightarrow} \mathrm{NO}+\mathrm{N} \quad \mathrm{k}_{1}=1,8 \cdot 10^{14} \mathrm{e}^{\frac{-318 \frac{\mathrm{kJ}}{\mathrm{mol}}}{\mathrm{RT}}} \frac{\mathrm{cm}^{3}}{\mathrm{~mol} \cdot \mathrm{s}} \\
& \mathrm{N}+\mathrm{NO}_{2} \stackrel{\mathrm{k}_{2}}{\rightarrow} \mathrm{NO}+\mathrm{O} \quad \mathrm{k}_{2}=9,0 \cdot 10^{9} \mathrm{e}^{\frac{-318 \frac{\mathrm{kJ}}{\mathrm{mT}}}{\mathrm{RT}}} \frac{\mathrm{cm}^{3}}{\mathrm{~mol} \cdot \mathrm{s}} \\
& \mathrm{N}+\mathrm{OH} \stackrel{\mathrm{k}_{3}}{\rightarrow} \mathrm{NO}+\mathrm{H} \quad \mathrm{k}_{3}=2,8 \cdot 10^{13} \quad \frac{\mathrm{cm}^{3}}{\mathrm{~mol} \cdot \mathrm{s}}
\end{aligned}
$$

For gas engines the proportion of nitric oxides formed in reaction (1) is $100 \%$ of their total emission [4]. Due to the very high flame temperature and the dissociation $\mathrm{N}_{2}=2 \mathrm{~N}$. $\mathrm{N}_{2}$ is not formed directly in reaction $\mathrm{NO}_{2}=\mathrm{N}+\mathrm{O}_{2}$.

\section{Laminar speed of combustion}

Combustion as the basic process of reaction of fuel with oxygen always occurs in the laminar layer. The layer can be compared to several mean free paths and so, when describing the phenomena taking place in the flow with combustion, we always use the model of laminar flame. Its basic parameter is the laminar speed of flame propagation $\mathrm{S}_{\mathrm{L}}$, defined as the speed of the perpendicular propagation of the flame front in the mixture. In the literature there are many methods of analytical determination of $\mathrm{S}_{\mathrm{L}}$. The most frequently quoted are those by Mallard and Le Chatelier and the theory by Zeldowicz-Frank-Kamieniecki-Semenow, abbreviated as Z-FK-S [5-8]. An analysis of the definition of the laminar

a)
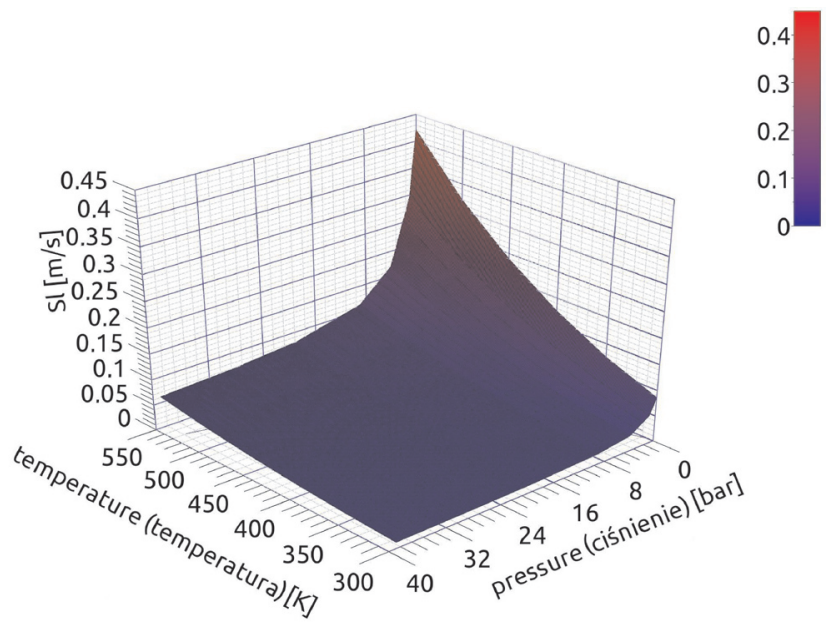

wych, takich jak ciśnienie $\mathrm{P}=1-40$ bar, współczynnik nadmiaru powietrza $\lambda=1,8$ oraz temperatury mieszanki palnej w zakresie $300-500 \mathrm{~K}$.

Obliczenia wykonano dla dwóch rodzajów paliw gazowych o składach podanych w tab. 1.

\section{Adiabatyczna temperatura plomienia}

Adiabatyczną temperaturę płomienia oblicza się na podstawie wielu równań opisujących proces utleniania paliwa na podstawie nierównowagowego mechanizmu, tzn. takiego który obejmuje tylko czas palenia się mieszanki we froncie płomienia. Rezultaty obliczeń adiabatycznej temperatury spalania przedstawiono na rys. $1 \mathrm{a}$ i $1 \mathrm{~b}$.

Wartość maksymalnej temperatury spalania silnie zależy od rodzaju spalanego paliwa a także od warunków prowadzenia procesu spalania. Jej wartość odgrywa również ważną rolę $\mathrm{w}$ procesie formowania się tlenków azotu w komorze spalania według termicznego mechanizmu tworzenia się NO opisanego przez Zeldowicza [2] według reakcji (1) i (2) uzupełnionego reakcją nr (3) podaną przez Lavoie [3].

Dla silników gazowych udział tlenków azotu powstających według reakcji (1) stanowi 100 \% całkowitej emisji tlenków azotu [4]. Ze względu na bardzo wysoką temperaturę płomienia i dysocjację $\mathrm{N}_{2}=2 \mathrm{~N}$ nie tworzy się bezpośrednio wg. reakcji $\mathrm{NO}_{2}=\mathrm{N}+\mathrm{O}_{2}$.

b)

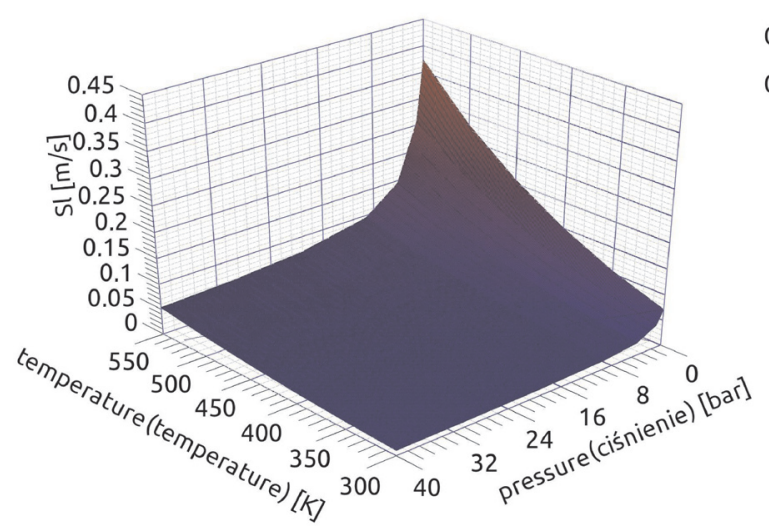

Fig. 2. Laminar flame speed as a function of ambient pressure and initial temperature; $\mathrm{a}$ - high methane), $\lambda=1.8, \mathrm{~b}-$ nitrified low-calorific gas, $\lambda=1.8$ Rys. 2. Laminarna prędkość spalania w funkcji ciśnienia otoczenia i temperatury początkowej; $a-g a z$ wysokometanowy, $\lambda=1,8, b-$ gaz niskokaloryczny zaazotowany, $\lambda=1,8$

speed of combustion shows that $\mathrm{S}_{\mathrm{L}}$ largely depends on the temperature of combustion and the temperature of ignition of the mixture. As demonstrated earlier, the maximum combustion temperature strongly depends on the temperature and pressure of the substrates and on the molar composition of fuel. Thus, Fig. $2 \mathrm{a}$ and $2 \mathrm{~b}$ present the calculated maps of laminar combustion speed for two different gas fuels from Tab. 1.

The above computations show that the laminar speed of combustion strongly depends on the temperature of the substrates and the pressure inside the reactor. The heating of

\section{Laminarna prędkość spalania}

Spalanie jako podstawowy proces reakcji paliwa z tlenem zachodzi zawsze w warstwie laminarnej. Warstwa ta jest porównywalna z kilkoma średnimi drogami swobodnymi, stąd w opisie zjawisk zachodzących w przepływie ze spalaniem posługujemy się zawsze modelem płomienia laminarnego. Podstawowym parametrem charakteryzującym płomień laminarny jest laminarna prędkość propagacji płomienia SL, definiowana jako prędkość rozprzestrzeniania się frontu płomienia w mieszance palnej w kierunku prostopadłym 
the fuel mixture before the combustion chamber results in an increase of the speed of the propagation of the flame. An inverse relationship occurs with an increase of the pressure in the reactor, when raising the static pressure slows down the speed of flame propagation. For fuels containing inert gases the value of $S_{L}$ decreases. Another parameter strongly affecting the laminar velocity of combustion is the coefficient of surplus air. For combustion of rich mixtures, the value of $\mathrm{S}_{\mathrm{L}}$ is much bigger than for lean mixtures $[9,10]$.

\section{Theoretical efficiency of the cycle of gas engine}

The theoretical efficiency of the cycle of a spark ignition engine (Otto cycle) can be determined from relation [11]:

$$
\eta_{\text {teor }}=1-\frac{1}{\varepsilon^{\kappa-1}}
$$

where: $\varepsilon$-compression ratio, $\kappa$-adiabatic index for exhaust gases.

This means that efficiency depends on the design of the engine and on molar fraction of the exhaust gases that work on the piston. The compression ratio can be increased, but only to some extent - because of, among other things, the durability of the engine.

For Waukesha engine series AT fuelled by high-methane gas the theoretical efficiency is from $56.6 \%$ for $\lambda=1.0$ to 58.8 for $\lambda=3.0$. With low-calorific gas the efficiency is minimally higher from $56.9 \%$ for $\lambda=1.0$ to $58.9 \%$ for $\lambda=3.0$. The effect on the efficiency is, therefore, insignificant. The mentioned above values will never be achieved for an overall efficiency of a real engine (systems of exhaust gases energy recovery are not considered).

In gas engines, maximum values are achieved by units working in power industry as prime movers for electricity generators. For such uses, the efficiency of power generation reaches nearly $49 \%$ (GE Jenbacher J920 - 48.7 \%, Wärtsilä 18V50SG-48.6\%, Rolls-Royce B35:40V16AG-48.3\%). This means the overall efficiency of the engine must be near $50 \%$ or higher. It must be remembered, however, that the engine moving the generator works at a constant speed, with all other settings being optimal.

Engines used in transmission systems work at variable settings depending on the requirements of the system operator. Thus, to optimize them means to ensure maximum efficiency for the full range of generation demand and rotation speed. The most important feature of the engines used in compressors and pumps is their reliability, which needn't go together with very high efficiency.

\section{Investigation of piston engines used in gas transmission system}

\section{Gas engine Cooper-Bessemer GMVH-12}

Before carrying out an analysis of the combustion process in the engine Cooper-Bessemer GMVH , indicating diagrams were made for the twelve cylinders of the unit to assess the uniformity of the engine work. The results are shown in Fig. 3. The analysis has shown very big heterogeneity in the distribution of pressure in the cylinders, reaching as much do jego frontu. W literaturze można spotkać wiele metod analitycznego wyznaczania $S_{L}$. Najczęściej przytaczanymi teoriami są teoria Mallarda i Le Chateliera oraz teoria Zeldowicz-Frank-Kamieniecki-Semenow, skrótowo oznaczana Z-FK-S [5 - 8]. Analiza definicji laminarnej prędkości spalania pokazuje, że istotny wpływ na $\mathrm{S}_{\mathrm{L}}$ ma temperatura spalania oraz temperatura zapłonu mieszanki palnej. Jak przedstawiono wyżej, maksymalna temperatura spalania silnie zależy od temperatury i ciśnienia substratów oraz składu molowego paliwa. Stąd na rys. 2 a i $2 b$ przedstawiono obliczone mapy laminarnej prędkości spalania uzyskane dla dwóch różnych paliw gazowych podanych w tab. 1 .

Powyższe wyniki obliczeń wskazują, że wartość laminarnej prędkości spalania zależy silnie od temperatury substratów oraz ciśnienia panującego w reaktorze. Podgrzanie mieszanki palnej przed doprowadzeniem jej do komory spalania powoduje wzrost prędkości propagacji płomienia. Odwrotna zależność występuje przy zwiększaniu ciśnienia w reaktorze, gdzie podniesienie sprężu spowalnia prędkość propagacji płomienia. Dla paliw zawierających w swoim składzie gazy inertne wartość $S_{L}$ spada. Innym parametrem mającym duży wpływ na wielkość laminarnej prędkości spalania jest współczynnik nadmiaru powietrza. Dla procesów spalania bogatych mieszanek $\mathrm{S}_{\mathrm{L}}$ przyjmuje dużo większe wartości niż dla procesów spalania mieszanek ubogich $[9,10]$.

\section{Sprawność teoretyczna obiegu silnika gazowego}

Sprawność teoretyczną obiegu silnika z zapłonem iskrowym (obieg Otto) wyznacza się z zależności (4) [11], gdzie: $\varepsilon$ - stopień sprężania, $\kappa$ - wykładnik adiabaty dla spalin.

Oznacza to, że sprawność zależna jest od konstrukcji silnika i składu molowego gazów spalinowych, które wykonują pracę na tłoku. Stopień sprężania można zwiększać, ale tylko w pewnym zakresie - ze względu m.in. na wytrzymałość silnika.

Dla silnika Waukesha serii AT zasilanego gazem wysokometanowym teoretyczna sprawność wynosi od 56,6\% dla $\lambda=1,0$ do $58,8 \%$ dla $\lambda=3,0$. Przy wykorzystaniu gazu niskokalorycznego sprawność jest minimalnie wyższa, bo wynosi od $56,9 \%$ dla $\lambda=1,0$ do $58,9 \%$ dla $\lambda=3,0$. Wpływ na sprawność jest więc nieistotny. Uzyskane wartości nigdy nie zostaną osiągnięte w przypadku sprawności ogólnej rzeczywistego silnika (nie są brane pod uwagę układy odzysku energii ze spalin itp.).

W odniesieniu do silników gazowych maksymalne wartości osiągane są przez jednostki wykorzystywane w energetyce, stosowane jako źródła napędu generatorów prądotwórczych. Dla takich zastosowań sprawność wytworzenia energii elektrycznej sięga prawie $49 \%$ (GE Jenbacher J920 - 48,7 \%, Wärtsilä 18V50SG - 48,6 \%, Rolls-Royce B35:40V16AG - 48,3\%). Oznacza to, że sprawność ogólna silnika musi być bliska lub wyższa niż $50 \%$. Należy pamiętać, że silnik napędzający generator pracuje przez cały czas z tą samą prędkością obrotową, przy optymalnych dla niej pozostałych ustawieniach.

Silniki wykorzystywane w systemie przesyłowym pracują przy zmiennych ustawieniach, zależnych od wymagań 


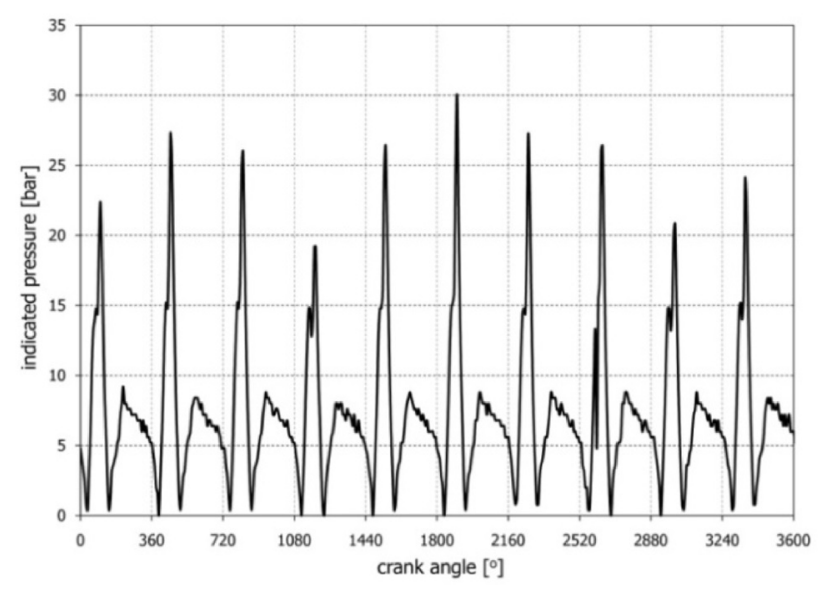

Fig. 3. Indicating diagram of a twelve cylinder, two-stroke gas engine, fuel - high methane, fuel valve without swirl

Rys. 3. Wykres indykatorowy dwunastocylindrowego, dwusuwowego silnika gazowego, gaz paliwowy - wysokometanowy, zawór paliwowy bez zawirowania

as 20 bar. The non-uniformity of pressure is a symptom of the faulty process of combustion, misfirings, etc., resulting in excessive emission of unburned hydrocarbons, and in the lowering of the engine efficiency. Additionally, such big differences in consecutive cylinders result in an increase of pressure in the crank-piston system.

The non-uniformity of ignition can be partially eliminated, e.g. by using a fuel valve increasing the swirl of the gas fed into the cylinder. Such device is shown in Fig. 4.

Indicating diagrams of combustion in the engine with an injection valve are more uniform (Fig. 5). The gas is fed at an angle to the valve axis, which improves swirl and
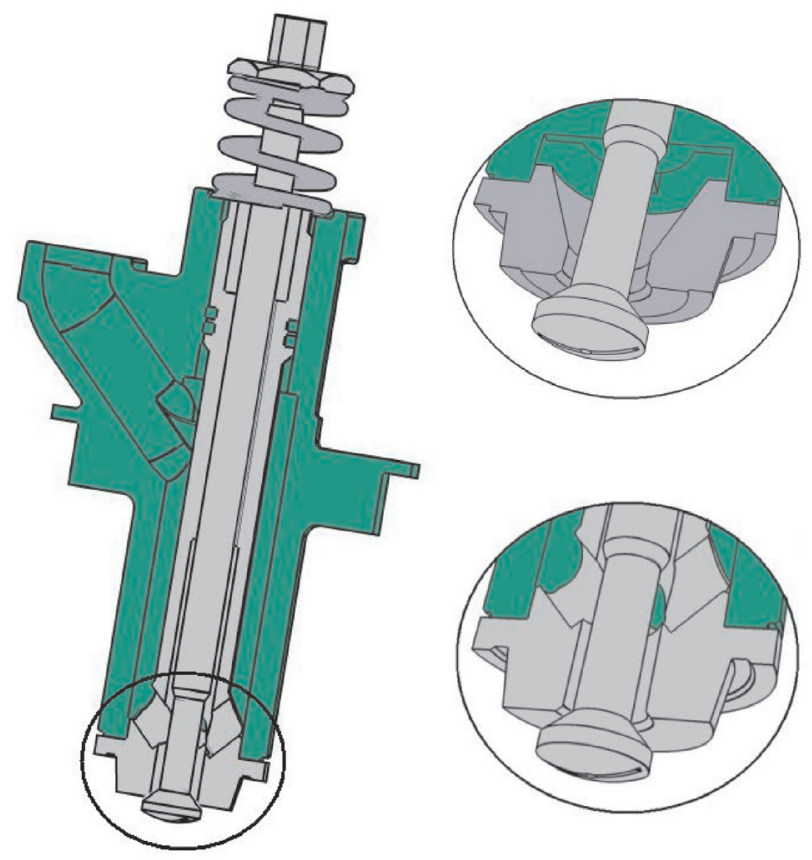

Fig. 4. Injection valve used in motor compressor series GMVH, a - old version, $\mathrm{b}$ - new version (with swirl)

Rys. 4. Zawór wtryskowy zastosowany w motosprężarkach serii GMVH, $a$-stara wersja, $b$-nowa wersja (z zawirowaniem) operatora systemu. Jednostki takie musiałyby być zoptymalizowane pod względem najwyższej sprawności w całym zakresie obciążeń i prędkości obrotowej. Najważniejszą cechą silników napędzających sprężarki i pompy jest ich niezawodność, co niekoniecznie wiąże się z bardzo wysoką sprawnością.

\section{Badania silników tlokowych pracujących w systemie przesylowym gazu}

\section{Silnik gazowy Cooper-Bessemer GMVH-12}

Przed przystąpieniem do analizy procesu spalania paliw gazowych w silniku Cooper-Bessemer GMVH wykonano wykresy indykatorowe dla dwunastu cylindrów jednostki w celu określenia równomierności pracy silnika. Rezultaty pomiarów przedstawiono na rys. 3. Analiza wyników wykazała bardzo duże niejednorodności rozkładu ciśnienia w indykowanych cylindrach, dochodzące nawet do 20 bar. Nierównomierność ciśnień świadczy o nieprawidłowym procesie spalania, wypadaniu zapłonów, a w konsekwencji nadmiernej emisji niespalonych węglowodorów oraz obniżeniu sprawności silnika. Ponadto tak duże różnice ciśnień na kolejnych cylindrach powodują zwiększone naprężenia w układzie korbowo-tłokowym.

Nierównomierność zapłonu można częściowo wyeliminować na przykład przez zastosowanie zaworu paliwowego wywołującego zwiększone zawirowanie gazu dostarczanego do cylindra. Schemat takiego zaworu przedstawiono na rys. 4 .

Dla procesu spalania w silniku wyposażonym w zawory paliwowe $\mathrm{z}$ zawirowaniem wykresy indykatorowe są bardziej jednolite (rys. 5). Gaz jest doprowadzany pod kątem do osi zaworu, co poprawia zawirowanie i powoduje ujednorodnienie mieszanki palnej. Konsekwencją tego jest mniejsza emisja niespalonych węglowodorów.

Po modernizacji silnika wykonano pomiary emisji związków toksycznych oraz zanieczyszczeń emitowanych do atmosfery (rys. 6) oraz temperatury spalin za turbosprężarką.

Analiza ilościowa składu gazów spalinowych pokazuje wyraźną zależność emisji NO, CO oraz $\mathrm{C}_{\mathrm{x}} \mathrm{H}_{\mathrm{y}}$ od współczynnika nadmiaru powietrza $\lambda$. Zmniejszenie udziału molowego tlenu w mieszance palnej powoduje obniżenie adiabatycznej temperatury spalania, co przekłada się na mniejszy stopień dysocjacji termicznej tlenu cząsteczkowego na tlen atomowy, a tym samym obniżenie ilości tlenków azotu powstających zgodnie z reakcjami (1), (2) i (3). Wraz ze wzrostem $\lambda$ maleje również temperatura spalin opuszczających jednostkę.

\section{Silnik gazowy Waukesha AT}

Spalanie ubogich mieszanek paliw gazowych jest trudne, dlatego w nowoczesnych silnikach gazowych wykorzystuje się takie technologie, jak micropilot, czyli wtrysk pilotażowej niewielkiej dawki oleju napędowego lub komorę wstępnego spalania. Stosowanie takich rozwiązań ma na celu ułatwienie zapłonu mieszanki palnej. Jest to szczególnie ważne w sytuacji spalania paliw z dużą zawartością gazów inertnych, takich jak azot lub dwutlenek węgla. 

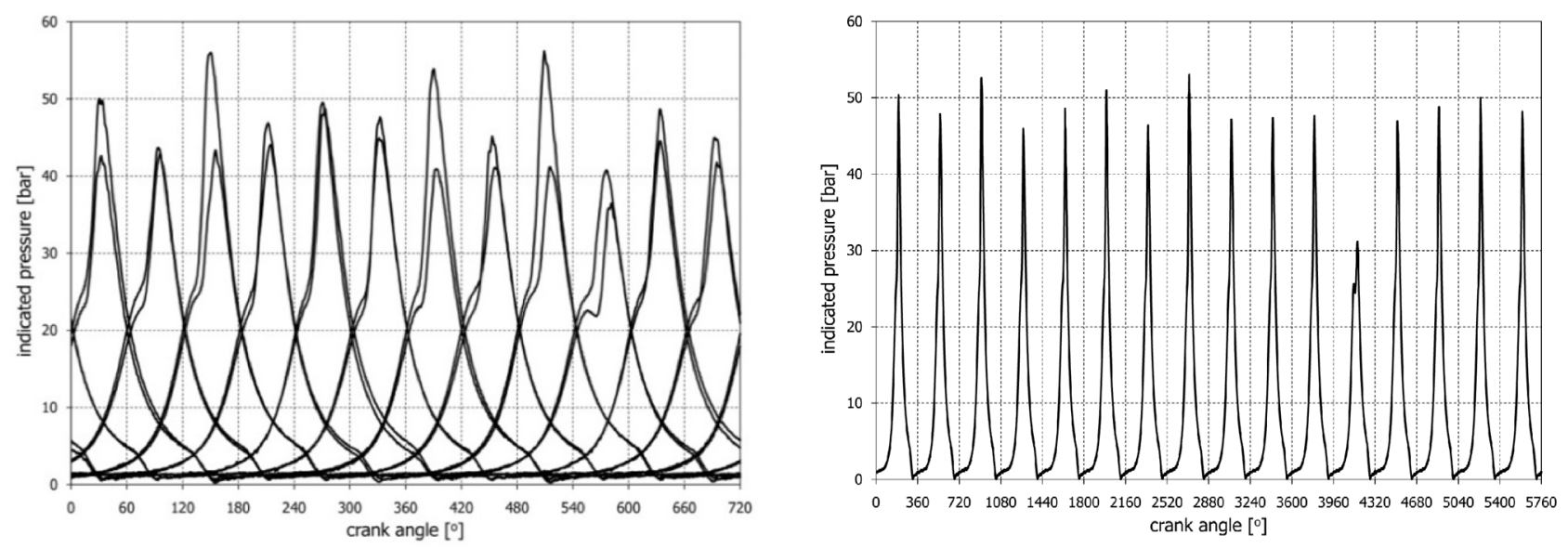

Fig. 5. Indicating diagram of a 12 cylinder, two-stroke gas engine, fuel - high methane, fuel valve with swirl, left side - for 12 cylinders, right side for a single cylinder

Rys. 5. Wykres indykatorowy dwunastocylindrowego, dwusuwowego silnika gazowego, gaz paliwowy - wysokometanowy, zawór paliwowy z zawirowaniem, lewa strona - dla 12 cylindrów, prawa strona - dla pojedynczego cylindra

produces higher homogeneity of the fuel mixture with a drop in emissions of unburned hydrocarbons.

After the engine was modified, emissions of toxic compounds and pollutants were measured (Fig. 6) as well as the temperature of exhaust gases after the turbocharger.

A quantitative analysis of the composition of exhaust gases shows a clear relation between emissions of $\mathrm{NO}, \mathrm{CO}$ and $\mathrm{C}_{\mathrm{x}} \mathrm{H}_{\mathrm{y}}$ and the coefficient of excess air $\lambda$. The lowering of the molar fraction of oxygen in the fuel mixture brings about the lowering of the adiabatic temperature of combustion, which in turn leads to a reduction of the thermal dissociation of molecular oxygen into atomic oxygen. This reduces the amount of nitric oxides formed in reaction (1), (2) i (3). As $\lambda$ increases, there is a decrease of the temperature of exhaust gases exiting the engine.

\section{Gas engine Waukesha AT}

Combustion of lean mixtures of gas fuels is a difficult task, and thus, in modern gas engines, technologies are used to remedy this, such as micro-pilot, i.e. the injection of a small pilot dose of diesel fuel or a prechamber. The objective is to facilitate the ignition of the fuel mixture. This is particularly important in combustion of fuels with a large content of inert gases, such as nitrogen or carbon dioxide.

The analysed gas engines Waukesha AT have, as standard equipment, a prechamber (Fig. 7). Rich mixture is fed into the prechamber, where ignition by an electric spark occurs; then hot exhaust gases produced by the combustion of this "ignition mixture" initiate the ignition of the lean mixture in the cylinder.

Lean fuel mixture is fed into the cylinder by an inlet system during the intake stroke. Measurements for fourstroke engines were carried out for two types of fuel gas: high-methane and nitrified low-calorific. The measured parameters were, like in the case of the two-stroke engine,
Analizowane silniki gazowe Waukesha AT zostały seryjnie wyposażone w komorę wstępną (rys. 7). Do komory wstępnej doprowadzana jest bogata mieszanka, której zapłon następuje od iskry elektrycznej, następnie gorące spaliny powstałe w wyniku spalania tej mieszanki inicjują zapłon ubogiej mieszanki znajdującej się w cylindrze.

Uboga mieszanka palna doprowadzana jest do cylindra układem dolotowym w trakcie suwu dolotu. Pomiary

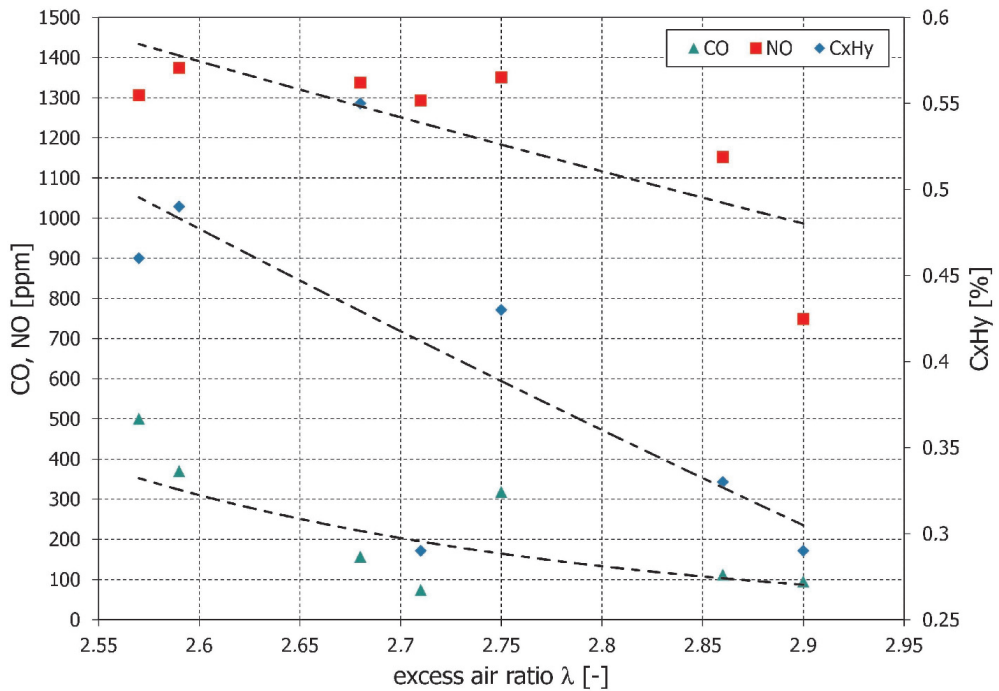

Fig. 6. Analysis of the exhaust gases composition for Cooper-Bessemer GMVH-12, fuel - high methane

Rys. 6. Wyniki analizy składu spalin dla Cooper-Bessemer GMVH-12, gaz paliwowy - wysokometanowy

silników czterosuwowych wykonano dla dwóch rodzajów paliwa gazowego: wysokometanowe i zaazotowane niskokaloryczne. Wielkościami mierzonymi, podobnie jak dla silników dwusuwowych, były emisje związków toksycznych i zanieczyszczeń emitowanych do atmosfery. Przykładowe rezultaty pomiarów przedstawiono na rys. 8 i 9 . Zależność emisji NO i CO od współczynnika nadmiaru powietrza jest 


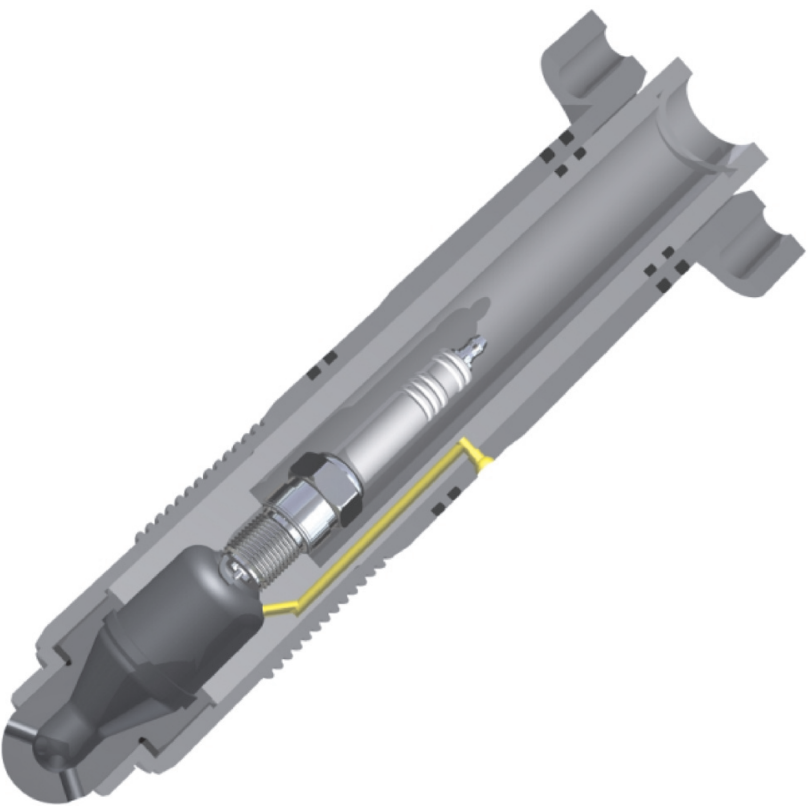

Fig. 7. Prechamber in Waukesha AT series engine (yellow - chamber gas supply)

Rys. 7. Komora wstepnego spalania w silniku Waukesha serii AT (kolor żólty - kanat doprowadzający gaz do komory)

emissions of toxic compounds and pollutants into the atmosphere. Some of the results are presented in Fig. 8 and Fig. 9. The dependence of $\mathrm{NO}$ and $\mathrm{CO}$ emission from the excess air ratio is the same as in the case of an Cooper-Bessemer GMVH-12 engine, while emission of $\mathrm{C}_{\mathrm{x}} \mathrm{H}_{\mathrm{y}}$ increases with the increasing the value of $\lambda$. The difference is due to the way of preparation of the air-fuel mixture. In the case of the Waukesha engine mixture is prepared in the carburetor and supplied to the cylinder as a homogeneous gas-air mixture (premix). The increase of excess air ratio value reduces the amount of fuel in the fuel-air mixture which causes the ignition of it more difficult. This results in the increasing the amount of unburned hydrocarbons. In the case of CooperBessemer two-stroke engine fuel is supplied directly to the cylinder by central poppet valve, which is controlled by the camshaft. The amount of fuel delivered in each cycle is almost the same - for the engine speed and load. According to the way the cylinder scavenging - cross-flow - the increase the amount of air supplied to the cylinder increases the degree of dilution of the exhaust gases and decrease the amount of unburned hydrocarbons in the increased volume of exhaust gases and flushing air.

\section{Conclusions}

The preliminary results of the investigation of the process of gas combustion in piston engines used in gas compressor stations have shown that the process can be optimized with regard to gas consumption and emissions of toxic compounds. The investigations should be continued so as to determine optimal working parameters for gas engines, particularly those fed with low-calorific gases.

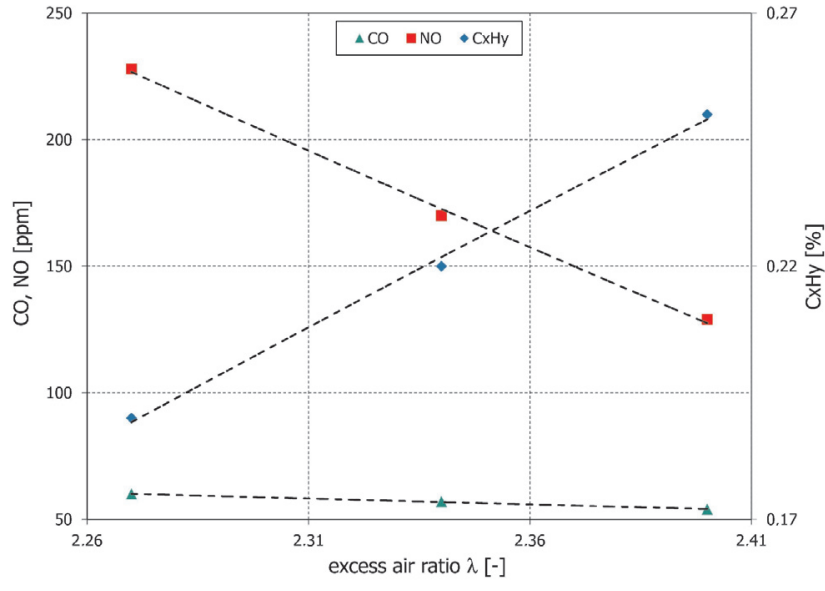

Fig. 8. Analysis of gas engine exhaust gases (fuel - high methane) Rys. 8. Wyniki analizy spalin silnika gazowego (gaz paliwowy - wysokometanowy)

taka sama jak dla silnika Cooper-Bessemer GMVH-12, natomiast emisja $\mathrm{C}_{\mathrm{x}} \mathrm{H}_{\mathrm{y}}$ rośnie wraz ze wzrostem wartości $\lambda$. Różnica ta wynika ze sposobu przygotowania mieszanki paliwowo-powietrznej. Dla silnika Waukesha mieszanka przygotowywana jest w gaźniku i dostarczana do cylindra jako bardzo jednorodna mieszanina gazu i powietrza. Wzrost wartości współczynnika nadmiaru powietrza powoduje zmniejszenie ilości paliwa w mieszance paliwowo-powietrznej, co utrudnia jej zapłon. Skutkuje to zwiększeniem ilości niespalonych węglowodorów. W odniesieniu do silnika dwusuwowego Cooper-Bessemer paliwo dostarczane jest bezpośrednio do cylindra centralnym zaworem grzybkowym, który jest sterowany wałkiem rozrządu. Ilość paliwa dostarczanego w każdym cyklu jest prawie taka sama dla danych obrotów i obciążenia. Ze względu na sposób przepłukania cylindra - poprzeczny - zwiększenie ilości powietrza doprowadzanego do cylindra powoduje zwiększenie stopnia rozrzedzenia spalin i spadek ilości niespalonych węglowodorów w zwiększonej objętości spalin i powietrza płuczącego.

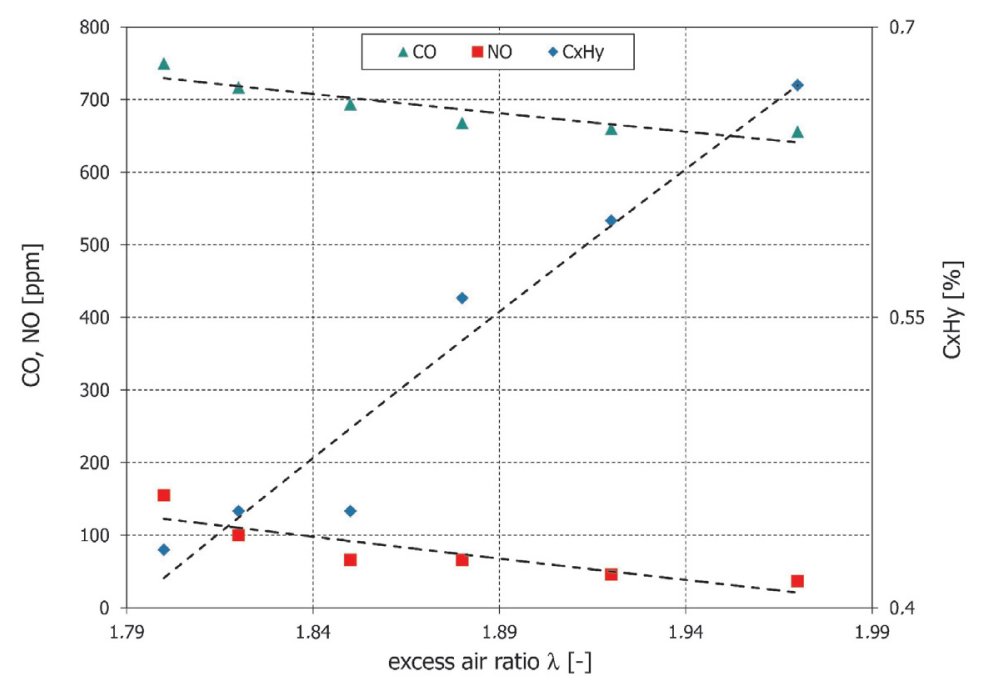

Fig. 9. Analysis of gas engine exhaust gases (fuel - high methane) Rys. 9. Wyniki analizy spalin silnika gazowego (gaz paliwowy-wysokometanowy) 
An improvement in combustion stability is achieved through the use of fuel valves with swirl and through better systems of ignition, which contributes to the lowering of emissions of toxic compounds and pollutants. Further research and the development of tool based on the GRI-Mech 3.0 which allows to take into account how the air-fuel mixture is prepared and charge exchange in the cylinder will helpful in optimizing the process of combustion in industrial gas engines.

The calculations presented in the paper have demonstrated that the theoretical efficiency of gas engines operating on low-calorific gases does not significantly differ from that of engines using high-methane fuels, what is more it is even higher. This is important at least because the numerous deposits of nitrified natural gases in Poland, which could be used to power cogeneration plants. The Directive 2004/8/ $\mathrm{EC}$ of the European Union promotes combined heat and energy economy as a future-proof solution, hence the topic is worth exploring.

\section{Acknowledgements}

A part of this research was made on behalf of PGNiG. S.A.; Branch Odolanow and as a development project no. N R06 0021 10_2010.02 of the National Centre for Research and Development.

\section{Bibliography/Literatura}

[1] GRI-Mech 2.11, An optimised detailed chemical reaction mechanism for methane combustion and NO formation and reburning, GRI Document No: GRI-97/0020, Gas Research Institute, Chicago 1997.

[2] Miller R., Davis G., Lavoie G., Newman C., Gardner T.: A super extended Zeldovich mechanism for $\mathrm{NO}_{\mathrm{x}}$ modeling and engine calibration, SAE, 1998.

[3] Kowalewicz A.: Podstawy procesów spalania. WNT, Warszawa 2000.

[4] United States Environmental Protection Agency, AP42, Fifth Edition, Compilation of Air Pollutant Emission Factors, Vol.1: Stationary Point and Area Sources.

[5] Blasiak W., Nabil R.: Experimental study: thermal performance of ceramic regenerative heat exchengers used in HiTAC regenerative burning systems, 25th Topic Oriented Technical Meeting, Stockholm, Sweden, October 2003.

[6] Cabra R., Chen J.-Y. i in.: Lifted methane-air flames in a vitiated coflow, Combustion and Flame, 2005, Vol. 143, s. 491-506.

[7] Carrea E.: High temperature air combustion: application to lean high pressure combustors, 4th International Symposium on High Temperature Air Combustion And Gasification, Rome, Italy, November 26-30, 2001.

[8] Chomiak J.: Podstawowe problemy spalania. PWN, Warszawa 1977.

[9] Dobski T.: Combustion gases in modern technologies. Wydawnictwo Politechniki Poznańskiej, Poznan 2009.

[10] Ślefarski R.: Combustion of low calorific natural gases with highly preheated air. PhD Thesis Poznan University of Technology, 2008.

[11] Pischinger R., Klell M., Sams T.: Thermodynamik der Verbrennungskraftmaschine. Springer Wien, New York 2011.

\section{Podsumowanie}

Wstępne wyniki badań procesu spalania gazu w tłokowych silnikach gazowych pracujących w tłoczniach gazu wykazały, że istnieje możliwość zoptymalizowania ich pracy pod kątem zużycia gazu oraz emisji szkodliwych związków. Badania powinny być kontynuowane w celu znalezienia optymalnych parametrów pracy dla silników gazowych, zwłaszcza tych zasilanych gazami niskokalorycznymi.

Poprawa stabilności spalania przez zastosowanie zaworów paliwowych z zawirowaniem oraz zastosowanie nowych rozwiązań zapłonu przyczynia się do obniżenia emisji związków toksycznych oraz zanieczyszczeń. Dalsze badania oraz stworzenie narzędzia bazującego na GRI-Mech 3.0 i pozwalającego na uwzględnienie sposobu przygotowania mieszanki paliwowo-powietrznej oraz wymiany ładunku w cylindrze będą pomocne przy optymalizacji procesu spalania w przemysłowych silnikach gazowych.

Przedstawione w pracy wyniki obliczeń wskazują, że teoretyczne sprawności silników gazowych zasilanych paliwami niskokalorycznymi nie odbiegają znacząco od sprawności silników zasilanych paliwami wysokometanowymi. Ma to znaczenie chociażby ze względu na liczne złoża gazów ziemnych zaazotowanych występujących w Polsce, które mogłyby zostać wykorzystane do napędzania układów kogeneracyjnych. Dyrektywa 2004/8/EC Unii Europejskiej promuje skojarzoną gospodarkę cieplno-energetyczną jako przyszłościowe rozwiązanie, dlatego temat jest wart zainteresowania.

\section{Podziękowania}

Część badań była wykonana na zlecenie PGNiG S.A. oddział w Odolanowie oraz w ramach projektu rozwojowego Narodowe Centrum Badań i Rozwoju w ramach umowy nr: N R06 0021 10_2010.02.

Jakub Rojewski, MEng - Postgraduate in the Faculty of Working Machines and Transportation at Poznan University of Technology.

Mgr inż. Jakub Rojewski - doktorant na Wydziale Maszyn Roboczych i Transportu Politechniki Poznańskiej. e-mail:jakub.rojewski@doctorate.put.poznan.pl

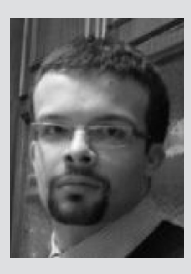

Rafał Ślefarski, DEng - doctor in the Faculty of Machines and Transportation at Poznan University of Technology.

Dr inż. Rafat Ślefarski-adiunkt na Wydziale Maszyn Roboczych i Transportu Politechniki Poznańskiej. e-mail: rafal.slefarski@put.poznan.pl

Jacek Wawrzyniak, MEng - Postgraduate in the Faculty of Machines and Transportation at Poznan University of Technology, Gas compressor station manager at PGNiG SA Branch Odolanów.

Mgr inż. Jacek Wawrzyniak - doktorant na Wydziale Maszyn Roboczych i Transportu Politechniki Poznańskiej, kierownik działu Tłocznia Gazu w PGNiG S.A oddziat w Odolanowie. 